\title{
Middle Miocene foraminifera from Canals (Valencia, western Mediterranean). Biostratigraphic and palaeoenvironmental aspects
}

\author{
Ignacio GARCÍA-SANZ*, Juan USERA, Jordi GUILLEM \& Carmen ALBEROLA
}

Departament de Botànica i Geologia, Universitat de València. Dr. Moliner, 50. 46100, Burjassot, Valencia, España. igarsan3@uv.es; Juan.Usera@uv.es; Jorge.Guillem@uv.es; Carmenalberola12@gmail.com

* Corresponding author

García-Sanz, I., Usera, J., Guillem, J. \& Alberola, C. 2020. Middle Miocene foraminifera from Canals (Valencia, western Mediterranean). Biostratigraphic and palaeoenvironmental aspects. [Foraminíferos del Mioceno medio de Canals (Valencia, Mediterráneo occidental). Aspectos bioestratigráficos y paleoambientales]. Spanish Journal of Palaeontology, 35 (1), $89-106$.

Manuscript received 20 December 2017

Manuscript accepted 12 August 2019 https://doi.org/10.7203/sjp.35.1.17237

(C) Sociedad Española de Paleontología ISSN 2255-0550

\begin{abstract}
The age and the palaeoenvironmental conditions of the tap marls outcroppings near the locality of Canals in the south of the Valencia Province (E Spain) are discussed. Based on the planktonic foraminifera assemblages, mainly the species Globorotalia praemenardii, these tap marls are dated as Serravallian in age (middle Miocene). The analysis of the foraminiferal assemblages suggests a relatively wellventilated upper-middle bathyal environment, with only a moderate oxygen deficiency throughout most of the studied section. The rather cool waters indicated by the planktonic foraminifera (e.g. Globigerina bulloides) are compatible with the decreasing temperatures trend during the middle Miocene due to the extension of the Antarctic Ice Cap. The abundant diatoms and radiolaria, and the highly diverse benthic foraminiferal assemblages are also consistent with prevailing upwelling conditions and a high surface productivity and carbon flux. The apparent warming trend throughout the short section analysed, together with the sharp decrease in diversity and the rise of dysoxic species like Globobulimina affinis at the uppermost sample, might indicate either a shortterm warming episode or a restriction of upwelling currents,
\end{abstract}

\section{RESUMEN}

Se discuten la edad y las condiciones paleoambientales en que se depositaron las margas tap que afloran cerca de la localidad de Canals al sur de la provincia de Valencia (E España). A partir de las asociaciones de foraminíferos planctónicos, sobre todo de la presencia de la especie Globorotalia praemenardii, se propone para ellas una edad Serravaliense (Mioceno medio). El análisis de las asociaciones de foraminíferos sugiere un ambiente batial superior-medio, relativamente bien ventilado y con sólo una moderada deficiencia de oxígeno a lo largo de la sección estudiada. Las aguas más bien frías indicadas por las asociaciones de foraminíferos planctónicos (como Globigerina bulloides) son compatibles con la tendencia al descenso térmico que se produjo en el Mioceno medio debido a la extensión del casquete polar antártico. La abundancia de diatomeas y radiolarios y la alta diversidad de las asociaciones de foraminíferos bentónicos también son coherentes con el predominio de condiciones de upwelling y una alta productividad superficial. La aparente tendencia al calentamiento a lo largo de la corta sección estudiada junto con el marcado descenso en diversidad y el incremento de especies disóxicas como Globobulimina affinis en la muestra 
eventually resulting in more sluggish bottom circulation and less well-oxygenated waters.

Keywords: Foraminifera, middle Miocene, biostratigraphy, palaeoenvironment, Valencia, Spain.

\section{INTRODUCTION}

The geological aspects of the marine Miocene deposits of the Valencia Province (Valencian Community, Eastern Spain) have been specifically studied by several authors (Guignoux \& Fallot, 1926; Darder, 1929, 1945; Brinkmann, 1931), although they have been also included in more general surveys (IGME, 1976; Gutiérrez et al., 1984). In particular, the Miocene foraminifera from the Province of Valencia were first studied by Colom (1936); later Usera (1972, 1973, 1974a, 1974b, 1975) and Calvo Sorando et al. (1974) carried out more detailed analyses on palaeogeographic, taxonomic and biostratigraphic aspects of several local Miocene outcrops in the Valencia province, based on fossil foraminifera. Later on, Gebhardt (1994, 1999) extensively analysed the foraminiferal assemblages recovered in many sections from middle and upper Miocene marl beds in the Province of Alicante, including the palaeoecological conditions (oxygenation levels) and the palaeoceanographic fluctuations that existed during that time interval. More recently, a series of detailed works (Corbí, 2010, 2017; Corbí et al., 2010, 2016; Corbí \& Soria, 2016), partly based on planktonic foraminifera, have described the geology, biostratigraphy, palaeogeography and palaeoenvironmental conditions of the Bajo Segura Basin, also in the province of Alicante, although they are mainly focused on the upper Miocene and Pliocene.

The middle Miocene series in the south of the Valencia Province starts with a deposit of conglomerate and sandstones that uncorformably lie on Mesozoic materials. They are followed by sandy marls, which display at their uppermost part a thick bed of white or bluish marls locally known as tap. The top of this bed is eroded and covered mostly by Tertiary continental marls and clays and, in some places, by Quaternary travertine limestones.

The age of these marls has been variously attributed either to the middle or to the upper Miocene (IGME, 1975, 1976). Therefore a more detailed sampling of some of the Miocene outcrops seems necessary. This work presents the results of the study of one of these marine tap marls sections, near the locality of Canals (South of the Valencia Province).

The main goal of the present work is to determine more precisely the age of the studied section basing on its content in planktonic foraminifera. Additionally, different palaeoenvironmental characteristics, such as superior podrían estar señalando un episodio de calentamiento a corto plazo o la restricción de las corrientes de upwelling, lo que daría lugar a una circulación de fondo más lenta y a ambientes peor oxigenados.

Palabras clave: Foraminíferos, Mioceno medio, bioestratigrafía, paleoambiente, Valencia, España.

\section{MATERIAL AND METHODS}

A total of 13 samples ( $>50 \mathrm{~g})$ were recovered from a section located in the district of Canals (coordinates: $38^{\circ} 57^{\prime} 13^{\prime \prime} \mathrm{N}$ and $0^{\circ} 37^{\prime} 50.23^{\prime \prime} \mathrm{W}$ ), next to the A-35 freeway, between the localities of Moixent and Montesa (Figs 1a-1c) in the south of the Valencia Province. The section is composed by homogeneous whitish silty marls with no discernable facies change (Figs 1d-1f). Samples were extracted at 20$30 \mathrm{~cm}$ intervals along a $2.50 \mathrm{~m}$ profile, subdivided in two subsections $3.65 \mathrm{~m}$ apart to avoid covered and vegetated areas (Figs. 1e-1f), and included in plastic bags. In the laboratory they were weighted and left for $48 \mathrm{~h}$ in a hot water solution of $3 \%$ hydrogen peroxide $\left(\mathrm{H}_{2} \mathrm{O}_{2}\right)$ and $6 \%$ sodium hydroxide $(\mathrm{NaOH})$ in order to better disaggregate the sediments. Subsequently, the samples were washed over 250, 125 and $63 \mu \mathrm{m}$ mesh sieves, dried under hot lamps and dry-weighted. The $>125 \mu \mathrm{m}$ fraction was used for this study.

Samples contained abundant foraminifera and were also rich in diatoms, radiolarians and sponge spicules. In each sample at least 300 foraminiferal tests were picked, identified, counted and fixed in micropalaeontological slides. The taxonomic identification of the foraminifera was mainly based on Saavedra (1961), AGIP (1982), Kennett \& Srinivasan (1983), Papp \& Schmid (1985) and BouDagher-Fadel (2015) together with the website database of Hayward et al. (2017). The most representative species are shown in Figures 2-4.

The alpha diversity index $\alpha$ (or Fisher's alpha index) was calculated for the benthic foraminiferal assemblages in each sample. This index in based on the observation that many faunal distributions fit the logarithmic series (Fisher et al., 1943), which is fixed by two variables: the number of species $\mathrm{S}$ and the number of individuals $\mathrm{N}$, related by the formula $S=\alpha \ln (1+N / \alpha)$. The alpha index $\alpha$ cannot 

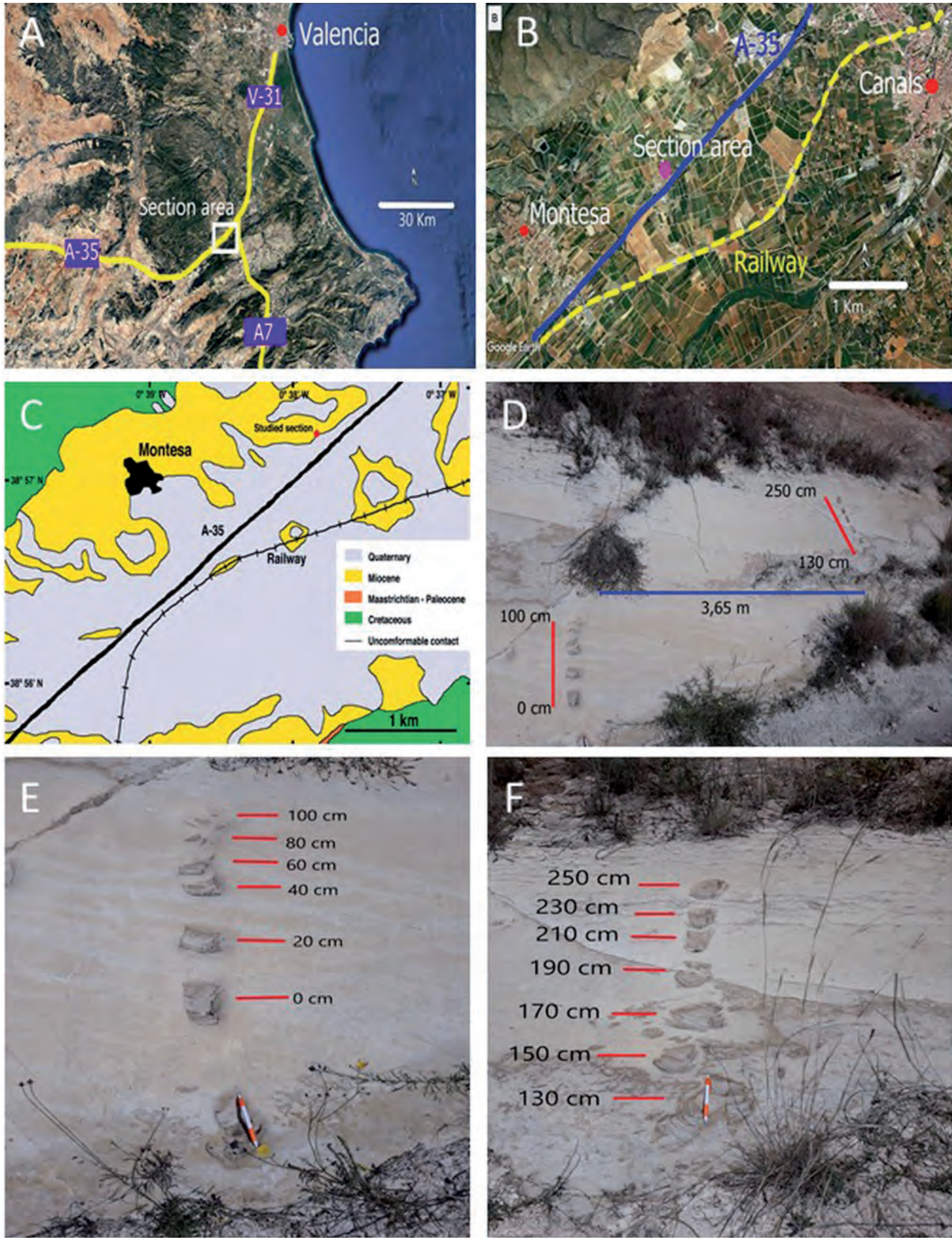

Figure 1. a) Google Earth view showing the geographic situation of the studied section in the Iberian Peninsula, western Mediterranean (coordinates: $38^{\circ} 57^{\prime} 13^{\prime \prime} \mathrm{N}$ and $0^{\circ} 37^{\prime} 50.23^{\prime \prime} \mathrm{W}$ ). b) Google Earth view of the Canals-Montesa area with the location of the studied section. c) Geologic scheme of the area and location of the studied section (redrawn and simplified from IGME, 1976). d) Studied profile showing the two sampled subsections. e) Sampling points along the lower subsection. f) Sampling points along the upper subsection. 


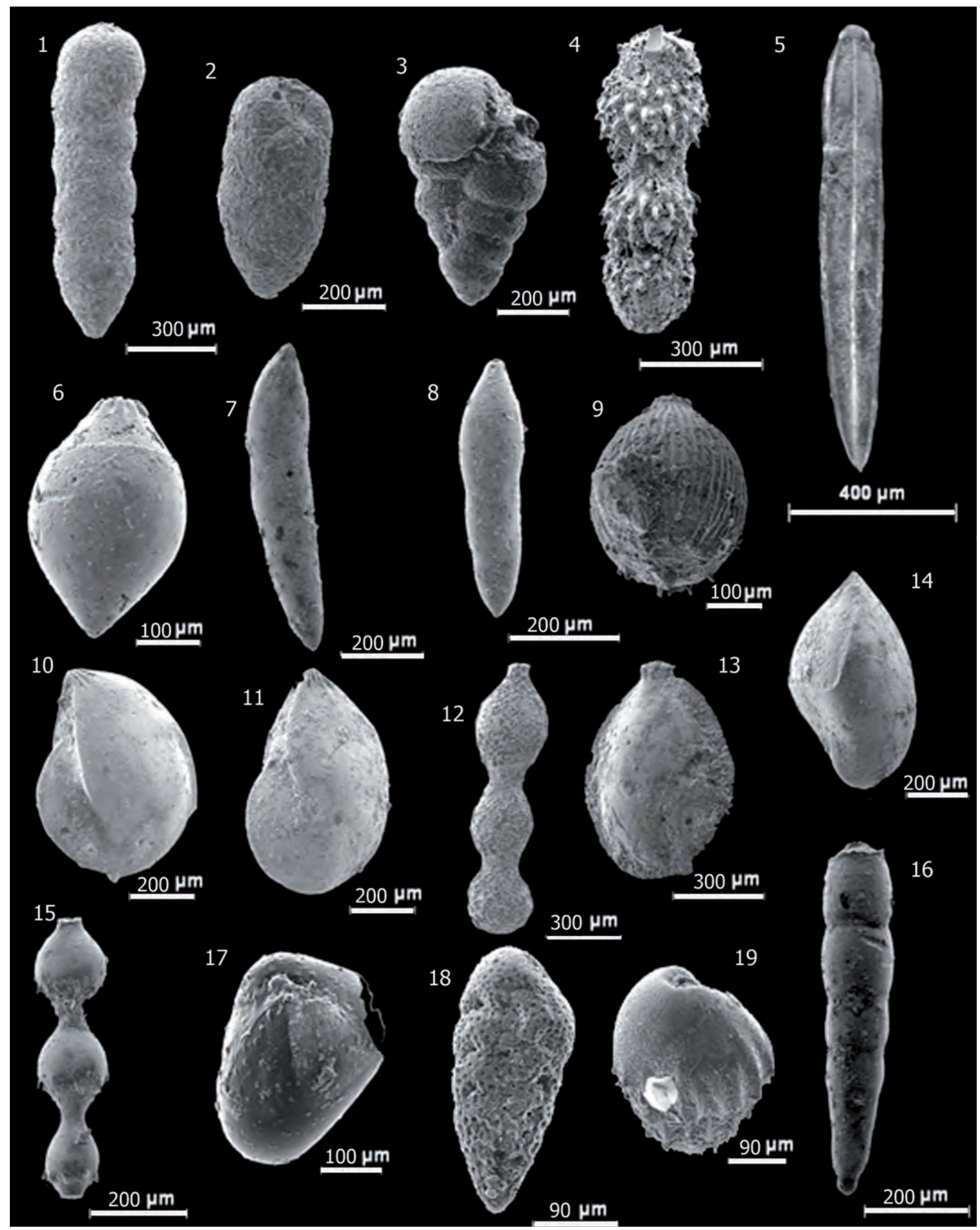


be algebraically calculated and specific software or tables are commonly used instead. Here we have employed the Appendix Table 4 of Hayek \& Buzas (1997). Although in three of the samples (at 60, 150 and $170 \mathrm{~cm}$ ) only 50-100 benthonic foraminifera were recovered, they still were included in the calculations for comparison purposes. The Shannon-Wiener diversity index H' was also calculated, from the formula $H^{\prime}=-\sum p_{i} \ln p_{i}$, where $p_{i}$ is the proportion of the $i^{\text {th }}$ foraminiferal species in the benthonic assemblage. This index has been here expressed as $\mathrm{N}_{1}=\mathrm{e}^{\mathrm{H}^{\prime}}$ (where e is the natural logarithm base) since 1) it can be more clearly interpreted as the number of equally common species that would correspond to an assemblage with diversity H' (Hill, 1973, see also Jost, 2006) and 2) it yields values similar in range to the Fisher alpha index, thus facilitating the inclusion of both curves in a single figure.

The $\mathrm{P}: \mathrm{B}$ ratio is here expressed as the percentage of planktonic tests: $\% \mathrm{P}=100 * \mathrm{P} /(\mathrm{P}+\mathrm{B})$ where $\mathrm{P}$ and $\mathrm{B}$ are respectively the number of planktonic and benthonic foraminifera. This ratio was then employed to carry out palaeobathymetric estimations using the regression provided by De Rijk et al. (1999) and based on data from the recent western Mediterranean: $\% \mathrm{P}=21.1 \cdot \ln (\mathrm{x})-64.1$, where $\mathrm{x}$ is the estimated depth (in m). An alternative expression proposed by Van der Zwaan et al. (1990) was also calculated according to the equation: $\mathrm{x}=\mathrm{e}^{3.58718+0.03534 * \% \mathrm{P} \text {, }}$ where $\mathrm{x}$ is the estimated depth, $\mathrm{e}$ is the base of the natural logarithm, and $\% \mathrm{P}^{\prime}=100 * \mathrm{P} /(\mathrm{P}+\mathrm{B}-\mathrm{S})$, where $\mathrm{S}$ denotes the number of foraminifera belonging to deep infaunal taxa, not directly related with depth, some of which are seen as indicators of stress conditions ( $\mathrm{S}$ taxa). We have followed here the list of $\mathrm{S}$ taxa proposed by Van der Zwaan et al. (1990) and updated by Van Hinsbergen et al. (2005). Accordingly, the following taxa: Bolivina spp. (except Bolivina pseudoplicata), non-costate Bulimina (in our material Bulimina aculeata and Bulimina elongata), Cancris spp., Fursenkoina spp., Globobulimina spp., Uvigerina spp., including Siphouvigerina hispida (Fig. 3.17) and Siphouvigerina proboscidea and Valvulineria spp., were computed as S taxa and thus excluded to calculate $\% \mathrm{P}^{\prime}$.

Planktonic foraminiferal species were classified according to their temperature preferences following Bicchi et al. (2003), based on previous studies by Bé \& Hutson (1977) and Spezzaferri (1992). According to this scheme, four categories were distinguished: cool, cool-temperate, warmtemperate and warm water indicators. Following Bicchi et al. (2003), in this study the species included in each category are: 1) cool: Globigerina spp. Here Globigerina bulloides (Fig. 4.6), Globigerina aff. G. diplostoma and Globigerina falconensis (Fig. 4.7), Catapsydrax spp., and Turborotalita quinqueloba; 2) cool-temperate: Globorotalia scitula (Fig. 4.15) and Globoturborotalita woodi; 3) warmtemperate: Globigerinella obesa (Fig. 4.8), Globoquadrina dehiscens (Fig. 4.11), Globoquadrina venezuelana, Paragloborotalia mayeri (Fig. 4.12), and aff. Tenuitella angustiumbilicata (Fig. 4.18); 4) warm: Globigerinoides spp., including here Trilobatus quadrilobatus (Fig. 4.10), Dentoglobigerina altispira (Fig. 4.5), Globorotalia praemenardii (Figs 4.13-4.14) and Orbulina spp.

A palaeothermic estimation curve was then generated from the sum of warm + warm-temperate species percentages (positive numbers) and cool + cool-temperate species (negative numbers).

In addition, benthonic species were classified according to their oxygen preferences. Following Kaiho (1994) and Gebhardt (1999) three categories were considered: 1) oxic species, indicating oxygen contents $>1.5 \mathrm{ml} / \mathrm{l}$ : Heterolepa dutemplei, Heterolepa praecincta (Fig. 3.12), Cibicides spp., Cibicidoides spp. and Globocassidulina subglobosa (Fig. 3.8); 2) suboxic indicators (groups B and C of Kaiho, 1994), most frequent with oxygen concentrations of 0.3-1.5 $\mathrm{ml} / \mathrm{l}$ : species of Cassidulina, Fissurina, Gyroidina including Hansenisca soldanii (Fig. 3.10), Lagena, Lenticulina including Neolenticulina peregrina (Fig. 2.13), Melonis, Nonion, Oridorsalis, Pullenia, Uvigerina, Trifarina, Valvulineria, Sphaeroidina bulloides (Fig. 3.18) and some Bulimina (e.g. B. aculeata and B. striata), Dentalina and certain Stilostomellidae, e.g. Neugeborina longiscata; $3)$ dysoxic indicators, characteristic of low oxygen concentrations (0.1-0.3 ml/1): Bolivina spp., Laevidentalina spp., Fursenkoina and Globobulimina spp.

The Benthic Foraminiferal Oxygen Index (BFOI), developed by Kaiho (1994) and expressed as BFOI $=100 *(\mathrm{O} / \mathrm{O}+\mathrm{D})$, where $\mathrm{O}$ and $\mathrm{D}$ are the number of specimens of respectively oxic and dysoxic indicators, was also calculated.

\section{RESULTS}

A list of all the foraminiferal species identified in the studied section of Canals can be found in Table 1

Figure 2. SEM images of foraminifera found in the Miocene beds of Canals. 1) Martinottiella communis. 2) Martinottiella gaudryinoides. 3) Siphotextularia affinis. 4) Amphicoryna hirsuta. 5) Dentalina vertebralis. 6) Glandulina laevigata. 7) Laevidentalina communis. 8) Laevidentalina mucronata. 9) Lagena striata. 10) Lenticulina calcar. 11) Lenticulina gibba. 12) Lotostomoides asperula. 13) Neolenticulina peregrina. 14) Saracenaria italica Defrance, 1824. 15) Siphonodosaria lepidula. 16) Strictocostella advena. 


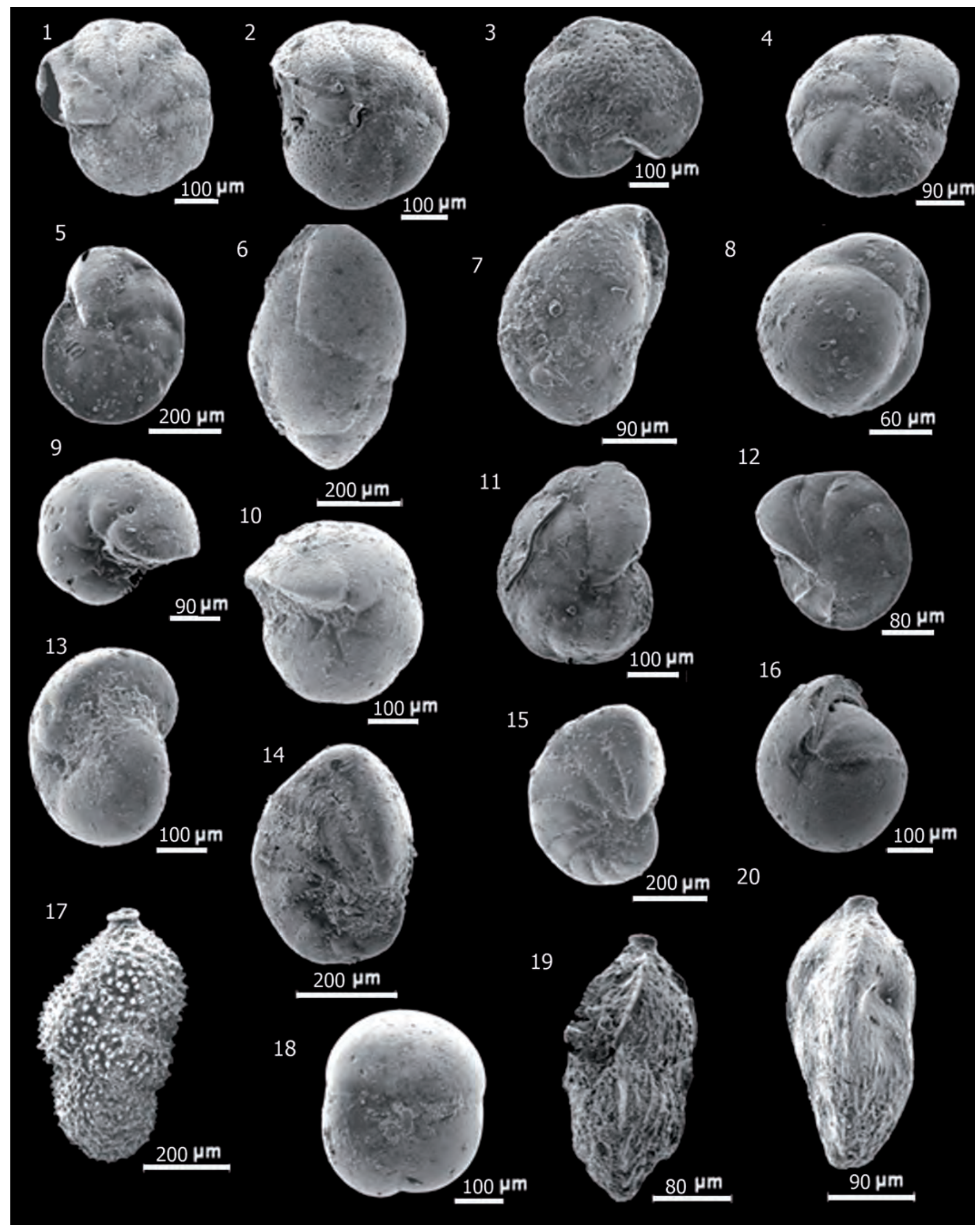


(Supplementary Information). In general, the degree of preservation is relatively good, but many specimens are small-sized or show sedimentary infillings that somewhat hinders the taxonomic identification. Diversity, palaeodepth and palaeothermic curve estimations together with BFOI and suboxic taxa relative abundance are all represented in Figure 5.

\subsection{Planktonic foraminifera}

The number of taxa in the planktonic assemblages, identified at least up to the genus level, ranges from 2 (at $0 \mathrm{~m}$ ) to 16 (at $2.30 \mathrm{~m}$ ). The relative abundance of some of the most frequent/relevant taxa throughout the section can be found in Figure 6 . The samples are largely dominated by Globigerina bulloides (Fig. 4.6), whose frequency varies between $20 \%$ and $85 \%$ of the assemblage. This is the only planktonic species continuously occurring throughout the whole section and, in most samples, it groups more than 50\% of the collected planktonic tests. Subdominant species are Globorotalia praemenardii (Figs 4.13-4.14), which exceeds $40 \%$ at $2.10 \mathrm{~m}$, or Globorotalia scitula (Fig. 4.15), which shows a peak ( $25 \%$ of the assemblage) at $0.20 \mathrm{~m}$. Also common, but irregularly distributed, are Globoquadrina dehiscens (Fig. 4.11), Globigerinita glutinata (Fig. 4.9) and Trilobatus quadrilobatus (Fig. 4.10), together with the less represented Globigerinita uvula and aff. Tenuitella angustiumbilicata (Fig. 4.18). The remaining species are very scarce, including some potential biostratigraphical markers, such as Dentoglobigerina altispira (Fig. 4.5) or Paragloborotalia mayeri (Fig. 4.12).

\subsection{Benthonic foraminifera}

Up to 142 benthic taxa were recognized in total (mostly Rotaliida and Lagenida) and the species richness in each sample varied between 25 (at $2.50 \mathrm{~m}$ ) and 53 (at $2.10 \mathrm{~m}$ ). Diversity is high (Fig. 5a), with Fisher alpha values varying between 15 and 25 and Shannon N1 between 15 and 31 throughout most of the studied profile. No discernable pattern is observed. In the uppermost sample $(2.50 \mathrm{~m})$, both diversity indices fall to their minimum scores (alpha index: 9 and Shannon N1: 11.85).

Figure 7 shows the relative abundance of the main taxa along the section. Unlike the planktonic assemblages, no particular benthic foraminiferal species is overwhelmingly dominant. Uvigerina barbatula (Fig. 4.2) is the most abundant species; it represents more than $30 \%$ of the assemblage at the base of the section $(0 \mathrm{~m})$ and fluctuates between 5 and $20 \%$ in the other samples. Globocassidulina oblonga (Fig. 3.7) also occurs throughout the whole profile but it only exceeds $5 \%$ of the assemblage between 0.20 and $0.60 \mathrm{~m}$. Other species above $10 \%$ of the assemblage in at least one sample include Haynesina depressula, with two prominent peaks at 0.60 and $1.70 \mathrm{~m}$, or Bulimina inflata, most abundant in the middle part of the section (from 0.80 to $1.70 \mathrm{~m}$ ). In the same category, Melonis pompilioides (Fig. 3.13), Pullenia bulloides (Fig. 3.16) and Sphaeroidina bulloides (Fig. 3.18) are more frequent in the upper part of the series, which is also the case of Globobulimina affinis (Fig. 3.6), although this latter species is only common in the uppermost sample. Also quite common are the Stilostomellidae, mainly represented by Strictocostella advena (Fig. 2.16), together with Caveastomella adolphina, Siphonodosaria consobrina, and Siphonodosaria lepidula (Fig. 2.15), with a prominent peak near the base of the series $(>25 \%$ at $0.20 \mathrm{~m}$ ) and gradually decreasing upwards (Fig. 7). Other relatively frequent (> 5\%) but less abundant species are Cibicides floridanus (Fig. 3.1), Cibicides haidingeri (Fig. 3.2), Cibicidoides lobatulus (Fig. 3.3), Cibicidoides pseudoungerianus, Gyroidina umbonata (Fig. 3.9), Hansenisca soldanii (Fig. 3.10), Heterolepa praecincta (Fig. 3.12), or Oridorsalis tenerus.

\subsection{Palaeoenvironmental parameters}

\subsubsection{P:B ratio}

Planktonic foraminifera represent above $50 \%$ of the total (planktonic + benthic) foraminiferal assemblages in all samples, with only one exception $(39.46 \%$ at $2.30 \mathrm{~m})$, and show a maximum of $91.34 \%$ at $0.60 \mathrm{~m}$. The estimated paleodepth resulting from the regression developed by De Rijk et al. (1999) based on western Mediterranean data is shown in Figure $5 \mathrm{~b}$ (a similar equation developed by these authors for the eastern Mediterranean yielded nearly identical results). Although there is a wide variation range (135 to $1582 \mathrm{~m}$ ), most estimations fall in the interval 200$1000 \mathrm{~m}$, corresponding to the middle-upper bathyal realm. The use of the expression determined by Van der Zwaan et al. (1990) yields a similar pattern but with less extreme

Figure 3. SEM images of foraminifera found in the Miocene beds of Canals. 1) Cibicides floridanus. 2) Cibicides haidingerii. 3) Cibicidoides lobatulus. 4) Cibicidoides robertsonianus. 5) Cibicidoides ungerianus. 6) Globobulimina affinis. 7) Globocassidulina oblonga. 8) Globocassidulina subglobosa. 9) Gyroidina umbonata. 10) Hansenisca soldanii. 11) Hanzawaia boueana. 12) Heterolepa praecincta. 13) Melonis pompilioides. 14) Nonion boueanum. 15) Nonion commune. 16) Pullenia bulloides. 17) Siphouvigerina hispida. 18) Sphaeroidina bulloides. 19) Trifarina angulosa. 20) Trifarina bradyi. 

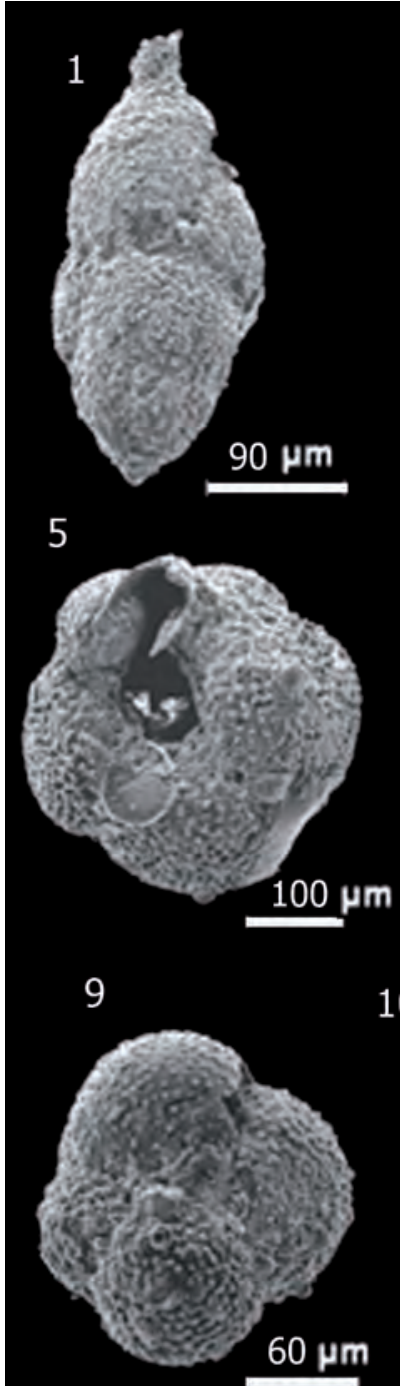

13

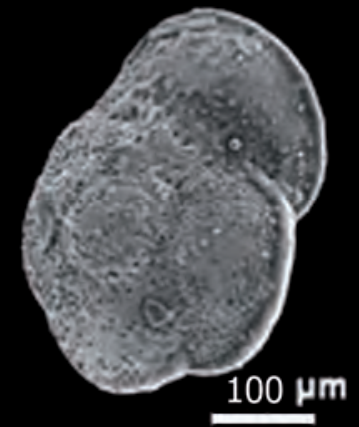

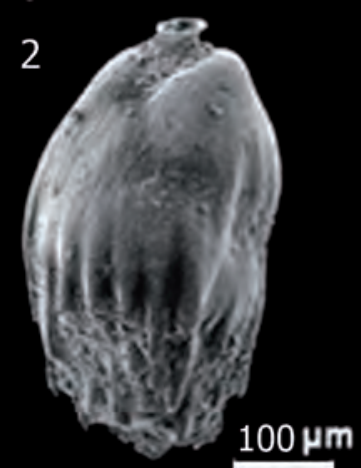

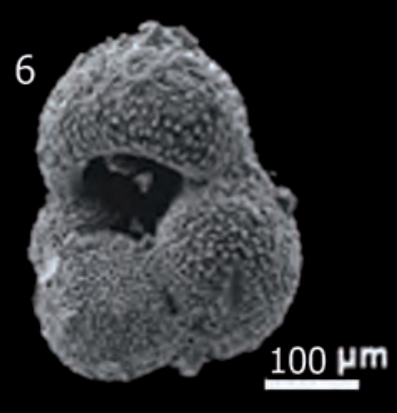

10

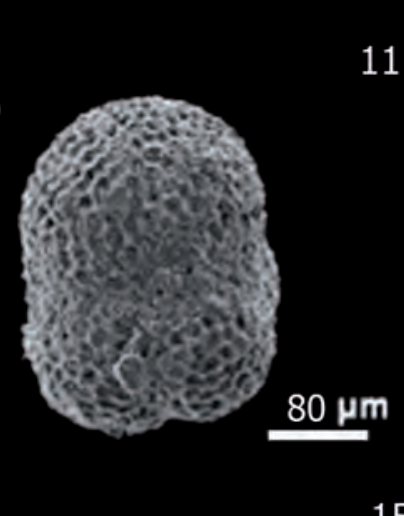

14

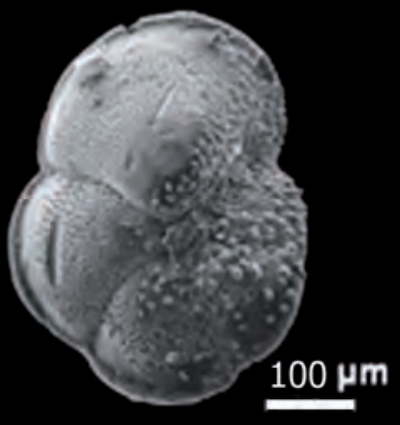

3
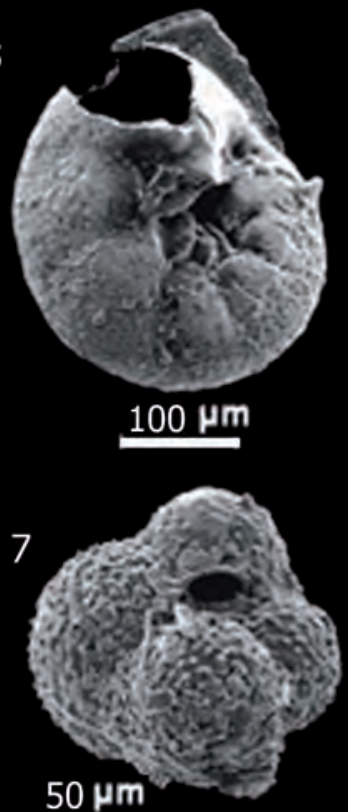
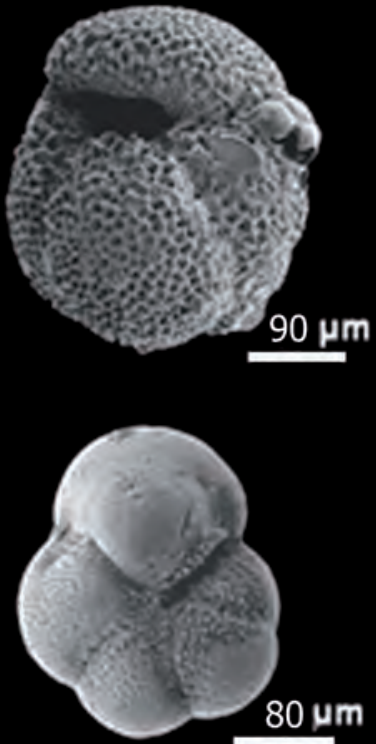

17

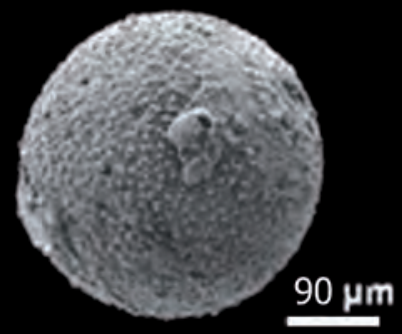

4
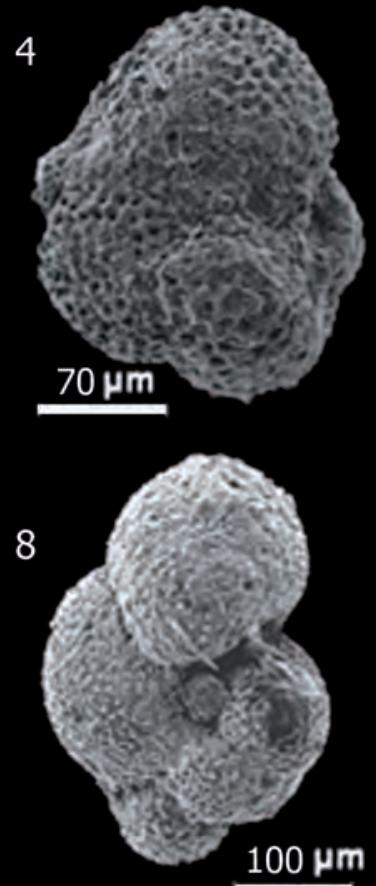

12

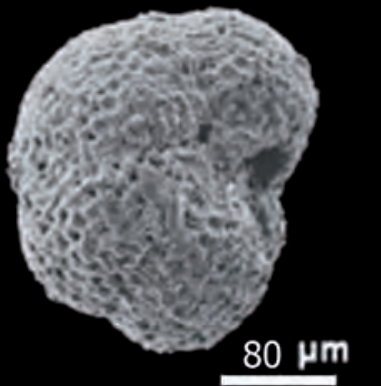

16

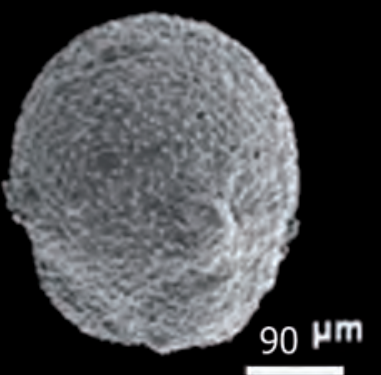

18

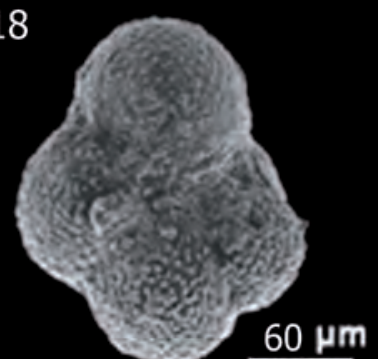


values (185 to $951 \mathrm{~m})$, with all samples but one $(2.10 \mathrm{~m})$ included in the interval 200-1000 m (Fig. 5b).

\subsubsection{Thermic curve}

The palaeothermic curve inferred from the composition of the planktonic foraminiferal assemblages is shown in Figure $5 \mathrm{c}$. Values oscillate between -94.8 and -2.7 and are always negative, thus pointing to rather cool waters. This estimation mostly derives from the notable dominance of the cool water indicator species G. bulloides. The curve shows some minor scale fluctuations within an apparently warming trend towards the top of the studied interval, reflected in a general increase of warm and warm-temperate water species like G. praemenardii or G. dehiscens.

\subsubsection{BFOI}

As other measured parameters, the BFOI curve (Fig. 5c) does not show any distinct pattern along the studied section but it systematically takes positive values, always $\geq+50$, with the sole exception of the uppermost sample $(+32)$, thus, suggesting relatively well-oxygenated waters throughout most of the series. This is reflected in oxic indicators (mostly Cibicides spp. and Cibicidoides spp.) exceeding dysoxic indicators (mainly represented here by Bolivina spp. and Globobulimina spp.) in most studied samples. Nevertheless, it should be pointed out that, in all samples, the most abundant category is still that represented by the suboxic species (also displayed in Fig. 5c).

\section{DISCUSSION}

\subsection{Biostratigraphy}

Several authors have redefined and improved the middle Miocene biostratigraphy for the Mediterranean area, based on planktonic foraminifera and calcareous nannoplankton from extensive well-preserved sections in Malta, Sicily, the Tremiti Islands (Adriatic Sea) and the Italian Peninsula (e.g. Foresi et al., 1998, 2001, 2002a, 2002b; Hilgen et al., 2000, 2003; Di Stefano et al., 2002, 2008; Lirer et al., 2002, 2007; Sprovieri et al., 2002a, 2002b; Lirer \&
Iaccarino, 2011). As already pointed out by previous works (e.g. Martinotti, 1981; Huddleston, 1984; Mazza, 1985; Miller et al., 1985, 1991; Coccioni et al., 1992), their results reflect that some plankton events in tropical open ocean waters are diachronous with respect to middle-high latitudes or to the Mediterranean Sea.

In the short section studied in Canals Globorotalia praemenardii (Figs 4.13-4.14) is the most abundant and conspicuous biostratigraphical marker. In the open ocean, tropical to subtropical waters, Wade et al. (2011) established its first occurrence (FO) in their M6 Zone (= N9 Zone of Blow, 1969, upper Langhian). According to Kennett \& Srinivasan (1983), its last occurrence (LO) is in the upper Serravallian (Zone N12 of Blow). In the Mediterranean Sea, the FO of this species has been recorded in the upper Langhian (Foresi et al., 1998), and constitutes one of the best foraminiferal events to approximate the Langhian/ Serravallian boundary (Iaccarino et al., 2004). Lirer et al. (2007) and Di Stefano et al. (2008) locate this event at the top of Subzone MMi5b of the biostratigraphic scheme of Sprovieri et al. (2002b) and Iaccarino et al. (2004). Although the species becomes scarce in the upper part of its range, Foresi et al. (1998) placed its LO close to the Serravallian/Tortonian boundary (Fig. 8).

Another important, but unfortunately much scarcer, biostratigraphical marker in Canals is Paragloborotalia mayeri (Fig. 4.12). Eleven tests attributed to this species have been recovered from the topmost two samples of the studied section, where they represent $1-2 \%$ of the planktonic assemblage. This species is very similar to Paragloborotalia siakensis, which has been considered a junior synonym by some authors (Bolli \& Saunders, 1982, 1985; Hilgen et al., 2000; Turco et al., 2001), whereas others differentiate between the two species (e.g. Blow, 1969; Kennett \& Srinivasan, 1983; Iaccarino, 1985; Foresi et al., 1998, 2001, 2002a, 2002b; Turco et al., 2002; Hilgen et al., 2003; Zachariasse \& Sudijono, 2012). Although the recovered specimens in Canals are generally small and poorly preserved, some show features considered as distinctive of $P$. mayeri (e.g. curved sutures in the spiral side vs. straight radial spiral sutures in P. siakensis). In the tropical and subtropical open oceans, the stratigraphic range of P. mayeri extends from Zone $\mathrm{O} 7$ (Chattian, upper Oligocene) to the top of Zone M11 (Tortonian, upper Miocene) in the biostratigraphic scheme of Wade et al. (2011). However, in the Mediterranean Sea (and also in the North Atlantic, see Lirer \& Iaccarino, 2005) this species

Figure 4. SEM images of foraminifera found in the Miocene beds of Canals. 1) Uvigerina auberiana. 2) Uvigerina barbatula. 3) Valvulineria complanata. 4) Catapsydrax unicavus. 5) Dentoglobigerina altispira. 6) Globigerina bulloides. 7) Globigerina falconensis. 8) Globigerinella obesa. 9) Globigerinita glutinata. 10) Trilobatus quadrilobatus. 11) Globoquadrina dehiscens. 12) Paragloborotalia mayeri. 13) Globorotalia praemenardii spiral view. 14) Globorotalia praemenardii umbilical view. 15) Globorotalia scitula. 16) Orbulina suturalis. 17) Orbulina universa. 18) aff. Tenuitella angustiumbilicata. 

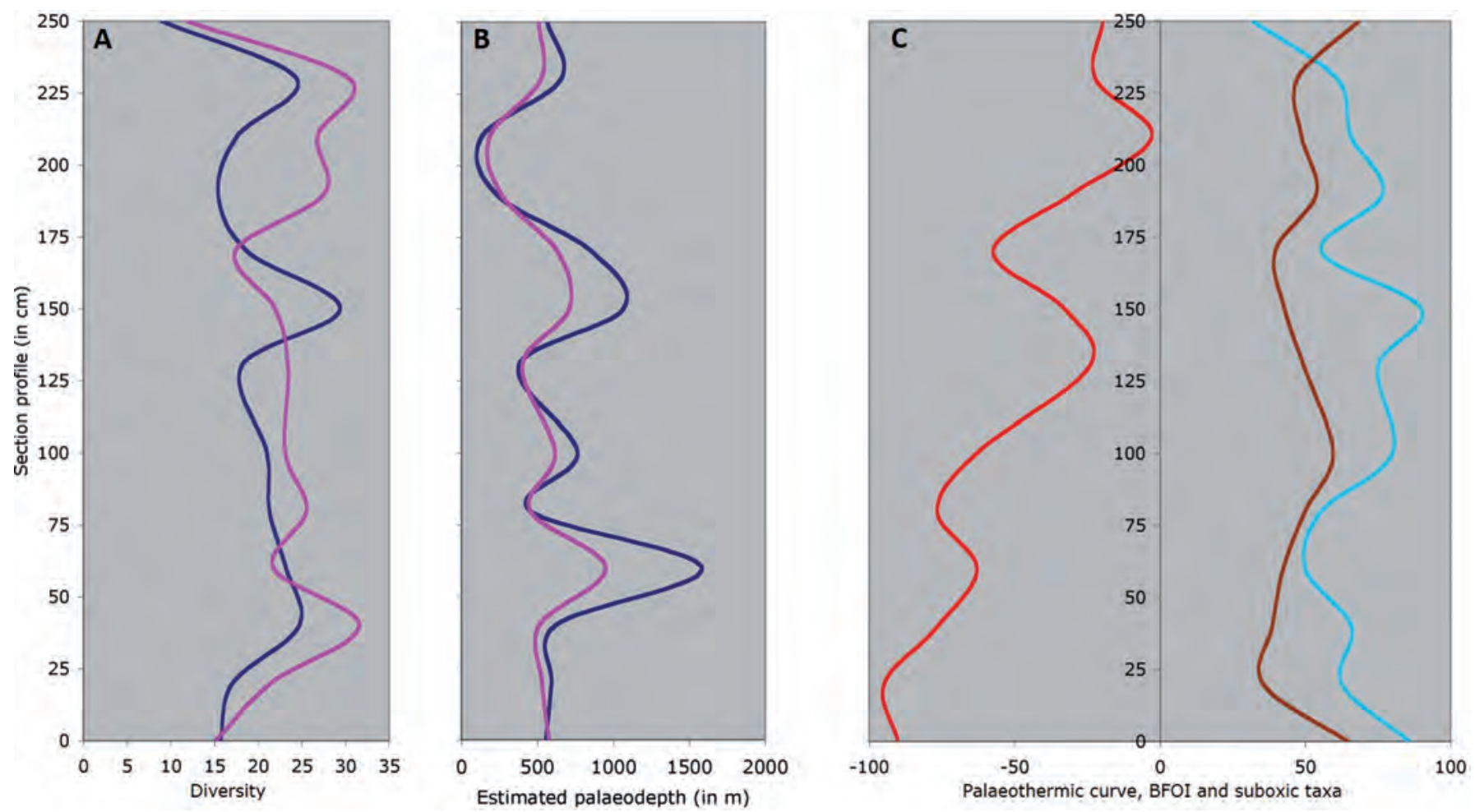

Figure 5. a) Benthic foraminiferal assemblages diversity along the studied section in Canals expressed by the Fischer alpha (blue) and Shannon-Wiener H' (pink) indices. The Shannon index H' is represented in the form N1 = $\mathrm{e}^{\mathrm{H}^{\prime}}$ (see text). b) Palaeodepth estimation (in $\mathrm{m}$ ) along the studied section in Canals based on the foraminiferal planktonic/benthic ratio and the expressions developed by De Rijk et al. (1999) for the recent western Mediterranean (blue) and by Van der Zwaan et al. (1990) (pink). c) Palaeothermic curve based on the composition of planktonic foraminiferal assemblages (red), oxygen index BFOI (light blue), and percentage of suboxic species (brown, groups B and C of Kaiho, 1994) along the studied section in Canals.

displays a much narrower range (Foresi et al., 1998, 2001, 2002b). Its FO is difficult to detect but its first common occurrence (FCO) and LO define the specific subzone MMi7b within the Serravallian (Sprovieri et al., 2002b).

The rest of planktonic foraminifera recovered in Canals show longer stratigraphic ranges or are scant. Nevertheless, all are coherent with a Serravallian age (see Fig. 8). In a detailed description of the Miocene series in the Tremiti Islands (Adriatic Sea), Foresi et al. (2001) place the first occurrence of the long-range extant G. bulloides (Fig. 4.6) in the later defined Subzone MM7a (Sprovieri et al., 2002b), although the FO of this species in the open ocean is in zone O5 (Chattian, upper Oligocene). On the other hand, G. dehiscens (Fig. 4.11), which is relatively abundant at the uppermost part of the studied section in Canals ( $>$ $20 \%$ at $2.50 \mathrm{~m}$ ), disappears in Tremiti somewhere near the Serravallian-Tortonian boundary (Foresi et al., 2001; but see Iaccarino, 1985, who extends its range up to the Tortonian in the Mediterranean), thus slightly preceding the last regular occurrence (LRO) of Dentoglobigerina spp., located in the lowermost Tortonian (Foresi et al., 2002b; Iaccarino et al., 2004). Dentoglobigerina altispira (Fig. 4.5) is very rare in Canals (only 4 specimens in the upper half of the studied section), but its occurrence together with $G$. dehiscens and other "globoquadrinids" suggests that the studied samples might precede, or at least be contemporaneous with the Serravallian Globoquadrina decline in the Mediterranean reported by various authors (e.g. Martinotti, 1981; Zachariasse \& Spaak, 1983).

The occurrence of aff. Tenuitella angustiumbilicata (Fig. 4.18) in Canals deserves a specific comment. This taxon is common in most of the studied section (although it never exceeds $10 \%$ of the assemblage). According to Kennett \& Srinivasan (1983), T. angustiumbilicata (as Globigerina angustiumbilicata) is one of the longestranging Cenozoic foraminiferal species (Eocene-Pliocene) and Foresi et al. (2001) reported it throughout the Miocene in the Tremiti islands (as "Globigerina" gr. angustiumbilicata-quinqueloba). However, accoring to Pearson et al. (2018), T. angustiumbilicata became extinct in the early Miocene and younger occurrences reported in the Neogene probably refer to homeomorphic forms. Since its taxonomic status is uncertain we have left this taxon here as aff. Tenuitella angustiumbilicata.

Other foraminiferal species used as biostratigraphical markers in the central Mediterranean are absent or have 
not been recognized in Canals. This can be attributed either to different taxonomic criteria, different specific environmental conditions or the palaeogeographical location of the studied section, near the Nord-Betic Strait, in close contact with the Atlantic. Therefore, the age of the studied section of Canals is Serravallian, and probably upper Serravallian, above subzone MMi7a, but the extreme scarcity of the important stratigraphic marker $P$. mayeri prevents further precision.

The proposed age for the tap marls of the locality of Canals is thus in agreement with previous studies of Colom (1936), Usera (1972, 1973, 1974a, 1974b, 1975) and Calvo Sorando et al. (1974), on the marine Miocene outcrops in the south of the Valencia Province. It is also consistent with the results of Gebhardt (1999) in the north of the Alicante Province. This author establishes a Serravallian transgressive phase with conglomerates and calcarenites, on which the tap marls would have been deposited during the Serravallian-Tortonian with no apparent discontinuity. The species reported in IGME (1976), which were used to ascribe these beds to the Tortonian, have not been found in our studied section.

\subsection{Palaeobathymetry}

As already pointed out, the results of the $\mathrm{P}: \mathrm{B}$ ratios suggest a middle-upper bathyal environment (200-1000 m, with average estimations of 525-650 m) for the studied section in Canals (Fig. 5b). The important presence throughout most of the studied section of planktonic species like $G$. scitula, that require a minimum depth of $\sim 500 \mathrm{~m}$ (Bé \& Tolderlund, 1971; Martins \& Dragão Gomes, 2004), and the composition of the benthic foraminiferal assemblages, are more or less in agreement with this estimation, although in many cases foraminiferal distribution is mainly controlled by factors others than depth. Some of the main benthic species (exceeding 10\% of the assemblage in at least one sample), such as $S$. bulloides (Fig. 3.18), $P$. bulloides (Fig. 3.16) or M. pompilioides (Fig. 3.13) are typically found in outer neritic and/or bathyal environments in modern oceans (Culver \& Buzas, 1981, 1982, 1983). This is also the case of Globocassidulina spp. or many current species of Uvigerina (Murray, 2006). In particular, Uvigerina barbatula (Fig. 4.2) is one of the dominant species in the Serravallian section studied in San Nicola
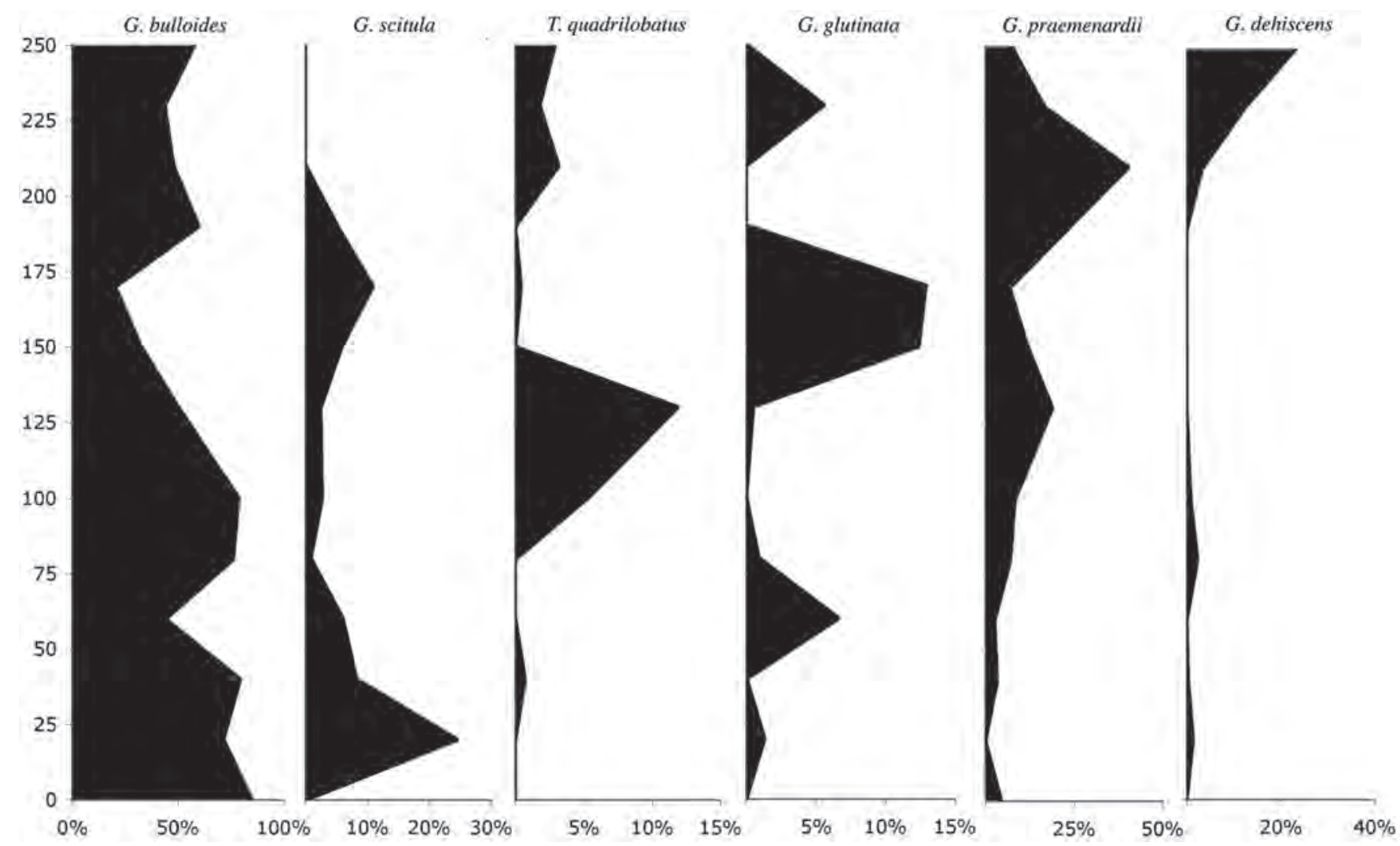

Figure 6. Relative abundance of the main planktonic foraminiferal species $(>10 \%$ in at least one sample) along the studied section in Canals. 


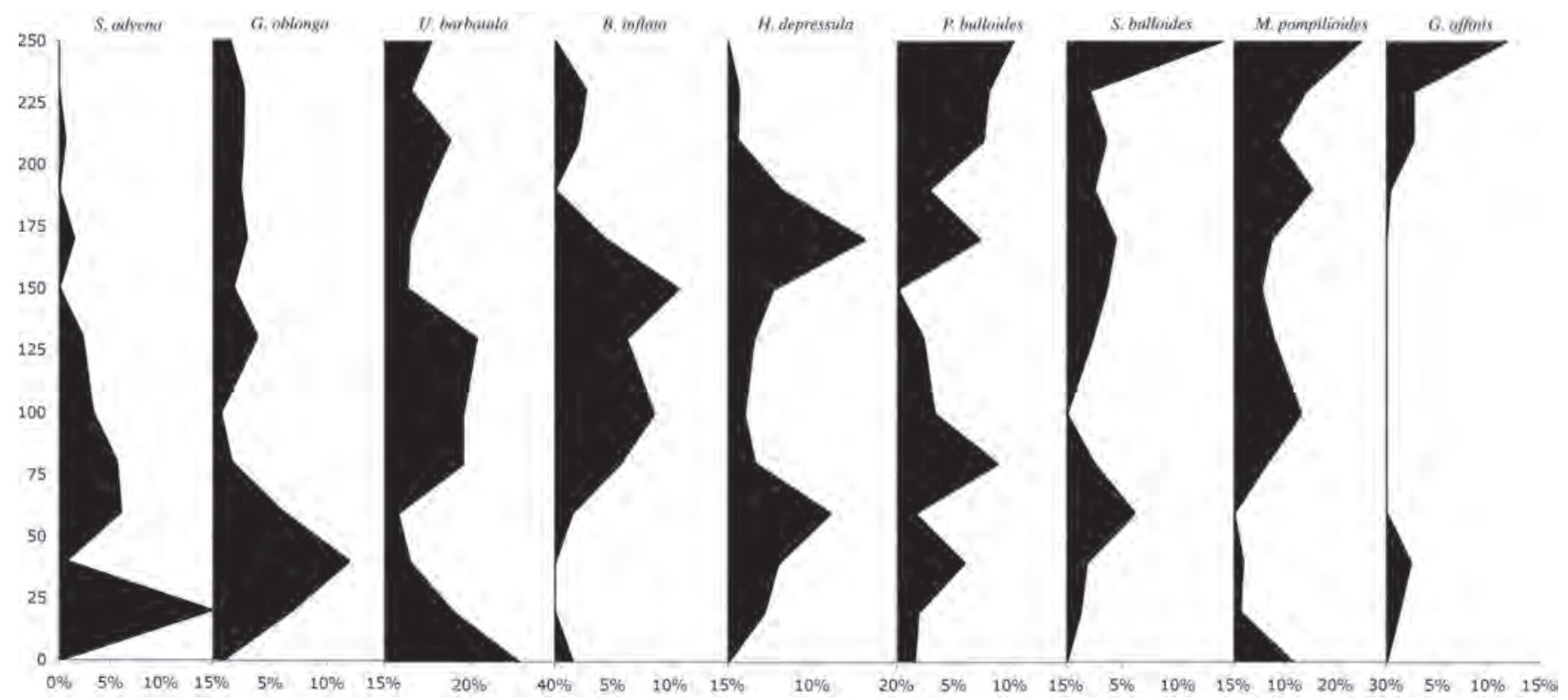

Figure 7. Relative abundance of the main benthic foraminiferal species $(>10 \%$ in at least one sample) along the studied section in Canals.

(Tremiti islands, Adriatic), with an estimated palaeodepth of around $1000 \mathrm{~m}$ (Russo et al., 2002). A similar bathymetric distribution is shown in present day oceans by other species, less abundant but still common in Canals, like $H$. soldanii (Fig. 3.10) or G. umbonata (Fig. 3.9). Lower bathyal indicators such as Cibicidoides wuellerstorfi, Oridorsalis umbonatus, S. hispida (Fig. 3.17) or O. tenerus represent as a whole only $\sim 3 \%$ of the assemblage on average, which is still below the 5\% limit considered by Gebhardt (1999) as an indication of truly lower bathyal $(\geq 1000 \mathrm{~m})$ environments.

On the other hand, the occurrence of the inner neritic species $H$. depressula suggests that part of the foraminiferal tests may have been transported by currents from shallower areas, even if this species only exceeds $10 \%$ of the total benthic assemblage in two of the less representative samples $(0.60$ and $1.70 \mathrm{~m})$, with $<100$ benthic tests recovered. Therefore, the estimations based on P:B ratios should be regarded with caution. Nevertheless, the whole available data are mostly coherent with an upper-middle bathyal environment for the studied section in Canals. The location of the North Betic Strait, within the outer Prebetic, would allow the formation of relatively deep basins ( $\geq 600 \mathrm{~m}$ ). The later tectonic evolution would close the communication with the Atlantic Ocean, eventually resulting in the establishment of a series of restricted basins and the deposit of lacustrine materials on these Miocene marls (Calvo et al., 1978).

\subsection{Palaeoenvironmental conditions}

The section studied in Canals is too limited $(2.50 \mathrm{~m})$ to reflect long-term climatic evolution. The apparently warming trend shown by the planktonic assemblages (Fig. 5c) might thus represent a local short-time climate fluctuation within the global cooling tendency during the Serravallian, originated in the increasing extension of the East Antarctic Ice Sheet (e.g. Miller et al., 1991; Flower \& Kennett, 1993, 1994; Turco et al., 2001; Zachos et al., 2001; Bicchi et al., 2003; Lirer et al., 2004). Alternatively, this pattern may simply reflect a short-term decrease of the prevailing upwelling conditions. The occurrence in these beds, and not in others included in the so-called blue marls (IGME, 1976), of numerous diatoms, radiolarians and sponge spicules are indicative of coastal upwelling phenomena, as those corresponding to the "Intermediate Episode" described in the Guadalquivir Basin (López García \& Bustillo, 1994). During this "Episode" the high productivity of the oceanic waters in the North Betic Strait became generalized and coincided with a relative tectonic stability. The interruption or restriction of upwelling cool deep waters would also result in an effective temporal warming of the water mass and in assemblages less dominated by relatively cool water species like $G$. bulloides, that has also been associated to phytoplankton blooms and upwelling phenomena (Hemleben et al., 1989; Thunell \& Sautter, 1992; Pujol \& Vergnaud Grazzini, 1995; Martins \& Dragão Gomes, 2004).

A first appraisal of the BFOI index results (Fig. 5c) indicates a high oxic environment along most of the studied section, with an estimated range of $3-\geq 6 \mathrm{ml} / 1$ of dissolved oxygen according to Kaiho (1999) and Murray (2006). However, the methodological approach, with the use of only categories B and C of Kaiho (1994) for suboxic indicators and the $>125 \mu \mathrm{m}$ instead of the $>250 \mu \mathrm{m}$ 

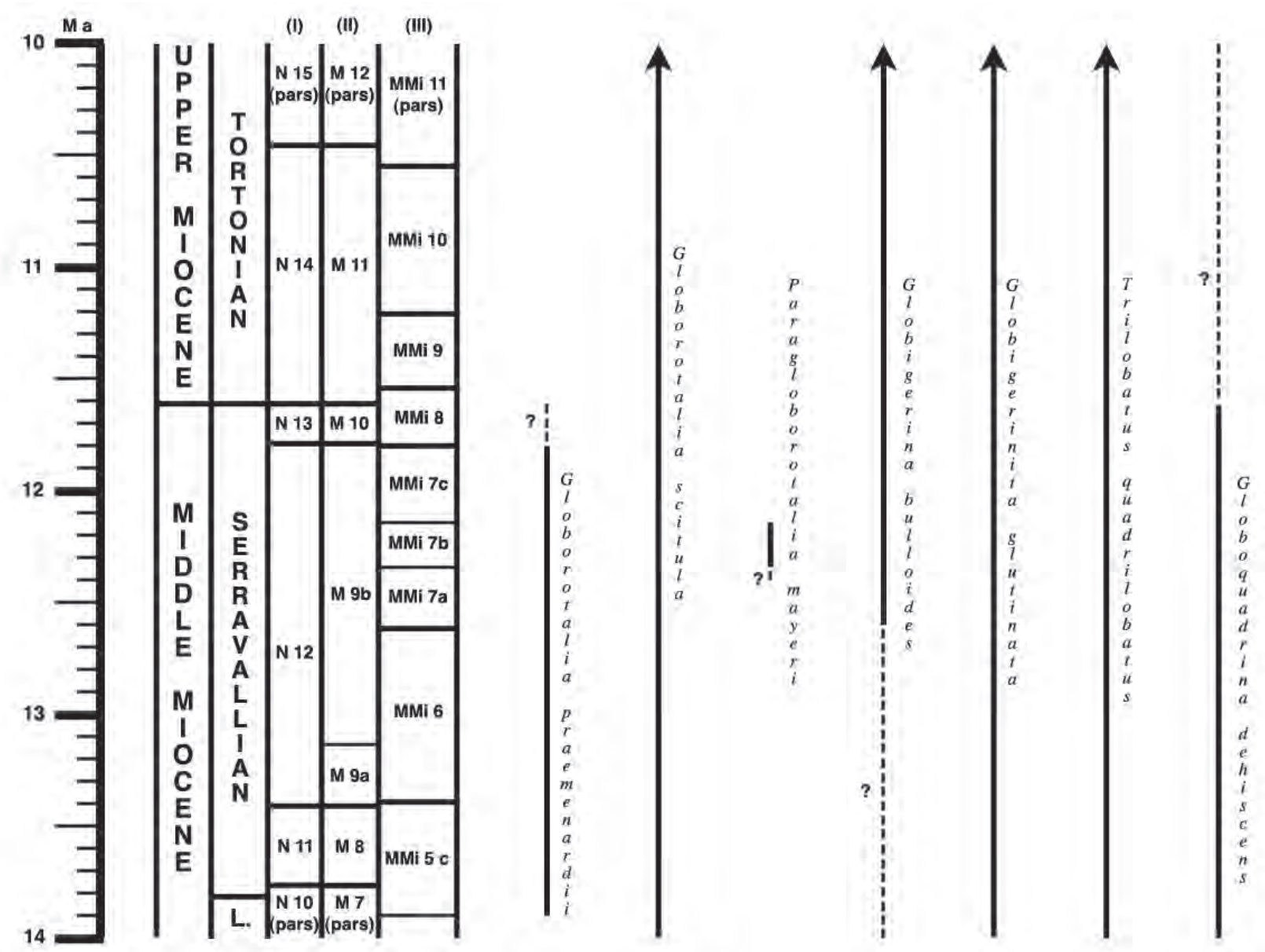

Figure 8. Mediterranean biostratigraphic ranges of some planktonic foraminiferal species found in Canals compared with the biostratigraphic schemes of (I) Blow (1969) and (II) Wade et al. (2011) for the tropical open ocean, and (III) Sprovieri et al. (2002b) and Iaccarino et al. (2004) for the Mediterranean. Equivalences between (I) and (II) are based on Wade et al. (2011). Boundary absolute ages follow the astronomical time scales of Lourens et al. (2004) for (I) and (II), and Laskar et al. (1993) for (III). Ranges of the foraminiferal species are based on several sources (see text). L = Langhian.

size-fraction employed by Gebhardt (1999), thus including many smaller mainly infaunal species (e.g. Bulimina, Bolivina or Uvigerina spp.), requires caution when interpreting the index BFOI in terms of specific ranges of dissolved oxygen. Uvigerina barbatula, the most abundant benthic species in Canals, is a suboxic indicator that tolerates a moderate oxygen deficiency. Nevertheless, Russo et al. (2002) found it associated with oxic species like C. ungerianus (Fig. 3.5), C. wuellerstorfi or $H$. dutemplei as the dominant species of an assemblage indicative of relatively well oxygenated waters in Serravallian deep bathyal $(\sim 1000 \mathrm{~m})$ sediments of the Tremiti islands (Adriatic Sea).

On the other hand, the high relative abundance of suboxic species $(\sim 50 \%$ on average, see Fig. $5 \mathrm{c})$, with numerous large Stilostomellidae, well-developed specimens of Dentalina, Laevidentalina, Lenticulina and abundant Uvigerina and Gyroidina spp., and the estimated depth range (upper-middle bathyal) for the Canals section suggest the influence of an Oxygen Minimal Zone (OMZ), but without a severe deficiency of dissolved oxygen, like in the Langhian-Serravallian section studied by Bellanca et al. (2002) in Ras-Il-Pellegrin (Malta). This would rather indicate a medium to low oxic environment $(\sim 1.2-3.2 \mathrm{ml} / 1$ for Kaiho, 1999 or 1.5-3 ml/1 for Murray, 2006).

The high diversity of the assemblages (Fisher and Shannon indices) together with the aforementioned abundance of diatoms, radiolaria and sponge spicules also point to the prevalence of coastal upwelling conditions with high surface productivity and carbon flux that would involve a certain degree of oxygen consumption. The uppermost part of the section, with the sharp decrease of the BFOI and diversity indices together with the rise of the dysoxic species $G$. affinis (Fig. 3.6), marks a certain environmental deterioration with less ventilated waters. In addition to the observed short-term warming inferred from the planktonic assemblages, this may indicate a temporal slowing or interruption of up-welling currents 
and consequently a more sluggish circulation and more stagnated waters towards the top of the studied section.

\section{CONCLUSIONS}

As inferred from the abundant occurrence of G. praemenardii the Miocene marls from the locality of Canals, in the south of the Valencia Province, can be ascribed to the Serravallian, within the open ocean zones N 10 to N 12 of Blow (1969), or M 7 to M 9 of Wade et al. (2011), which correspond to biozones MMi 5c to MMi 7 in the Mediterranean scheme of Sprovieri et al. (2002b) and Iaccarino et al. (2004). A more specific assignation to the upper Serravallian would require confirming the occurrence of the extremely scarce species $P$. mayeri or the analysis of other biostratigraphical markers (e.g. calcareous nannoplankton).

The studied materials were deposited in an uppermiddle bathyal environment as inferred from both the B:P ratios and the benthic foraminifera depth-markers. The plankton composition (foraminifera and abundant diatoms and radiolaria) is coherent with the climate cooling that developed during the middle Miocene as a consequence of the extension of the Antarctic Ice Cap and with the (possibly local) prevalence of upwelling phenomena, such as those identified in coetaneous materials from the Guadalquivir Basin. Within this context, the planktonic foraminifera suggest a short-term climate warming or, alternatively, a temporal episode of interruption / slowing of upwelling currents resulting in warmer waters towards the top of the studied section. In agreement with this, the highly diverse benthic foraminifera are consistent with an environment of high productivity and carbon flux and only a moderate deficiency in oxygen (low-medium oxic environment), reflecting the possible influence of a paleoOMZ that is expected to be present at upper-middle bathyal depths. The constriction of upwelling currents towards the top of the section would eventually result in a more sluggish water circulation, a less oxygenated bottom and less diverse foraminiferal assemblages.

\section{ACKNOWLEDGEMENTS}

We gratefully acknowledge the critical comments and suggestions of Carlos Martínez Pérez, Hugo Corbí and an anonymous reviewer that have greatly improved an earlier version of this manuscript. We are also indebted to Amelia Haba Sánchez for her helpful suggestions about the English version of the manuscript. This work has benefited from a CAISEP (Comisión de Ayudas a la Investigación de la Sociedad Española de Paleontología) research grant awarded to the first author IGS.

\section{REFERENCES}

AGIP 1982. Foraminiferi Padani (Terziario e Quaternario). Atlante Iconografico e Distribuzione Stratigrafica. AGIP S.p.A., 52 Tavole.

Bé, A.W.H. \& Hutson, W.H. 1977. Ecology of planktonic foraminifera and biogeographic patterns of life and fossil assemblages in the Indian Ocean. Micropaleontology, 23, 369-414.

Bé, A.W.H. \& Tolderlund, D.S. 1971. Distribution and ecology of living planktonic foraminifera in surface waters of the Atlantic and Indian oceans. In: The Micropalaeontology of Oceans (eds. Funnel, B.N. \& Riedel, W.R.). Cambridge, 105-149.

Bellanca, A., Sgarrella, F., Neri, R., Russo, B., Sprovieri, M., Bonaduce, G. \& Rocca, D. 2002. Evolution of the Mediterranean Basin during the late Langhian - early Serravallian: an integrated paleoceanographic approach. Rivista Italiana di Paleontologia e Stratigrafia, 108, 223239; doi: 10.13130/2039-4942/5472.

Bicchi, E., Ferrero, E. \& Gonera, M. 2003. Paleoclimatic interpretation based on Middle Miocene planktonic Foraminifera: the Silesia Basin (Paratethys) and Monferrato (Tethys) records. Palaeogeography, Palaeoclimatology, Palaeoecology, 196, 265-303; doi:10.1016/S00310182(03)00368-7.

Blow, W.H. 1969. Late Middle Eocene to Recent planktonic foraminiferal biostratigraphy. In: International Conference on Planktonic Microfossils, $1^{\text {st }}$ Geneva 1967 Proceeding (eds Brönnimann, P. \& Renz, H.H.). 1, 199-421.

Bolli, H.M. \& Saunders, J.B. 1982. Globorotalia mayeri and its relationship to Globorotalia siakensis and Globorotalia continuosa. Journal of Foraminiferal Research, 12, 39-50.

Bolli, H.M. \& Saunders, J.B. 1985. Oligocene to Holocene low latitude planktic foraminifera. In: Plankton Stratigraphy (eds. Bolli, H.M., Saunders, J.B. \& Perch-Nielsen, K.). Cambridge University Press, 155-262.

BouDagher-Fadel, M.K. 2015. Biostratigraphic and Geological Significance of Planktonic Foraminifera. UCLPRESS, 298 pp.

Brinkmann, R. 1931. Betikum und Keltiberikum in Südostspanien. Bëitrage zur Geologie der westlichen Mediterrangebiten, 6. Berlin (Spanish translation: Las cadenas Béticas y Celtibéricas del Sureste de España). Consejo Superior de Investigaciones Científicas. Instituto Lucas Mallada. Publicaciones Extranjeras sobre Geología de España, IV, 305-431.

Calvo, J.P., Ordóñez Delgado, S. \& Usera, J. 1974. Estudio del Terciario marino de la sierra del Mugrón (Prov. Albacete y Valencia). Acta Geológica Hispánica, 5, 174-178.

Calvo, J.P, Elizaga, E., López-Martínez, N., Robles, F. \& Usera, J. 1978. El Mioceno superior continental del prebético externo: Evolución del Estrecho nord-bético. Boletín Geológico y Minero, 89, 9-28.

Coccioni, R., Di Leo, C. \& Galeotti, S. 1992. Planktonic foraminiferal biostratigraphy of the upper Serravallianlower Tortonian Monte dei Corvi Section (Northeastern 
Apennines, Italy). Conferenza interdisciplinare di geologia sull'epoca miocenica con enfasi sulla sequenza umbro-marchigiana, abstracts and field trips, p. 53-56.

Colom, G. 1936. Los foraminíferos de las margas azules de Enguera (provincia de Valencia). Boletín de la Sociedad Española de Historia Natural, 36, 205-225.

Corbí, H. 2010. Los foraminíferos de la cuenca neógena del Bajo Segura (sureste de España). Bioestratigrafía y cambios paleoambientales en relación con la crisis de salinidad del Mediterrano. Ph.D. Thesis. Universidad de Alicante, $280 \mathrm{pp}$.

Corbí, H. 2017. El registro sedimentario de la Cuenca del Bajo Segura (SE España) a través del análisis de correspondencia: implicaciones paleoambientales. Estudios Geológicos, 73(2), e071. https://doi.org/10.3989/ egeol.42908.459.

Corbí, H. \& Soria, J. 2016. Late Miocene-early Pliocene planktonic foraminifer event-stratigraphy of the Bajo Segura basin: A complete record of the western Mediterranean. Marine and Petroleum Geology, 77, 10101027; doi: 10.1016/j.marpetgeo.2016.08.004.

Corbí, H., Pina, J.A. \& Soria, J.M. 2010. Bioestratigrafía basada en foraminíferos planctónicos para el Mioceno superior y Plioceno de la Cuenca del Bajo Segura (Cordillera Bética oriental). Geogaceta, 48, 71-74.

Corbí, H., Soria, J.M., Lancis, C., Giannetti, A., Tent-Manclús, J.E. \& Dinarès-Turell, J. 2016. Sedimentological and palaeoenvironmental scenario before, during, and after the Messinian Salinity Crisis: The San Miguel de Salinas composite section (western Mediterranean). Marine Geology, 379, 246-266. http://dx.doi.org/10.1016/j. margeo.2016.05.017.

Culver, S.J. \& Buzas, M.A. 1981. Distribution of Recent benthic foraminifera in the Gulf of México. Smithsonian Contributions to the Marine Sciences, 8, $898 \mathrm{pp}$.

Culver, S.J. \& Buzas, M.A. 1982. Recent benthic foraminiferal provinces between Newfoundland and Yucatán. Geological Society of America Bulletin, 93, 269-277.

Culver, S.J. \& Buzas, M.A. 1983. Recent benthic foraminifera provinces in the Gulf of México. Journal of Foraminiferal Research, 13, 21-31; doi: 10.2113/gsjfs.13.1.21.

Darder, B. 1929. La estructura geológica de los valles de Montesa y Enguera (provincia de Valencia). Memorias de la Real Sociedad Española de Historia Natural, 15, 603-610.

Darder, B. 1945. Estudio Geológico del sur de la provincia de Valencia y norte de la de Alicante. Boletín del Instituto Geológico y Minero de España, 57, 369-837.

De Rijk, S., Troelstra, S.R. \& Rohling, E.J. 1999. Benthic foraminiferal distribution in the Mediterranean Sea. Journal of Foraminiferal Research, 29, 93-103; doi: 10.2113/gsjfr. 29.2.93.

Di Stefano, E., Bonomo, S., Caruso, A., Dinares-Turell, J., Foresi, L.M., Salvatorini, G. \& Sprovieri, R. 2002. Calcareous plankton bio-events in the Miocene Case Pelecani section (southeastern Sicily, Italy). Rivista Italiana di Paleontologia e Stratigrafia, 108, 307-323; doi: 10.13130/2039-4942/5478.
Di Stefano, A., Foresi, L.M., Lirer, F., Iaccarino, S.M., Turco, E., Ornella Amore, F., Mazzei, R., Morabito, S., Salvatorini, G. \& Abdul Asís, H. 2008. Calcareous plankton high resolution bio-magnetostratigraphy for the Langhian of the Mediterranean area. Rivista Italiana di Paleontologia e Stratigrafia, 114, 51-76; doi: 10.13130/2039-4942/6369.

Fisher, R.A., Corbet, A.S. \& Williams, C.B. 1943. The relationship between the numberr of species and the number of individuals in a random sample of an animal population. Journal of Animal Ecology, 12, 42-58.

Flower, B.P. \& Kennett, J.P. 1993. Middle Miocene oceanclimate transition: High resolution oxygen and carbon isotopic records from Deep Sea Drilling Project Site 588 southwest Pacific. Paleoceanography, 8, 811-843; doi: 10.1029/93PA02196.

Flower, B.P. \& Kennett, 1994. The middle Miocene climatic transition: East Antarctic ice sheet development, deep ocean circulation and global carbon cycling. Palaeogeography, Palaeoclimatology, Palaeoecology, 108, 537-555; doi: 10.1016/0031-0182(94)90251-8.

Foresi, L.M., Iaccarino, S., Mazzei, R. \& Salvatorini, G. 1998. New data on Middle to Late Miocene calcareous plankton biostratigraphy in the Mediterranean area. Rivista Italiana di Paleontologia e Stratigrafia, 104, 95-114; doi: 10.13130/2039-4942/6114.

Foresi, L.M., Iaccarino, S., Mazzei, R., Salvatorini, G. \& Bambini, A.M. 2001. Il plancton calcareo (Foraminiferi e nannofossili) del Miocene delle Isole Tremiti. Palaeontographia Italica, 88, 1-62.

Foresi, L.M., Bonomo, S., Caruso, A., Di Stefano, E., Salvatorini, G. \& Sprovieri, R. 2002a. Calcareous plankton high resolution biostratigraphy (foraminifera and nannofossils) of the uppermost Langhian-lower Serravallian Ras Il-Pellegrin Section (Malta). Rivista Italiana di Paleontologia e Stratigrafia, 108, 195-210; doi: 10.13130/2039-4942/5470.

Foresi, L.M., Bonomo, S., Caruso, A., Di Stefano, A., Di Stefano, E., Iaccarino, S.M., Lirer, F., Mazzei, R., Salvatorini, G. \& Sprovieri, R. 2002b. High resolution calcareous plankton biostratigraphy of the Serravallian succession of the Tremiti Islands (Adriatic Sea, Italy). Rivista Italiana di Paleontologia e Stratigrafia, 108, 257273; doi: 13130/2039-4942/5474.

Gebhardt, H. 1994. Die Tap-Mergel in der Provinz Alicante (Südostspanien, Langhium bis Tortonium): Biostratigraphie, Paläogeographie und Paläoökologie. Berliner Geowissenschaftliche Abhandlungen. A 63, 1-149.

Gebhardt, H. 1999. Middle to Upper Miocene benthonic foraminiferal paleoecology of the Tap Marls (Alicante Province, SE Spain) and its palaeoceanographic implications. Palaeogeography, Palaeoclimatology, Palaeoecology, 145, 141-156; doi: 10.1016/S00310182(98)00110-2.

Guignoux, M. \& Fallot, P. 1926. Contributions à la connaissance des terrains Néogènes et Quaternaires marins sur les côtes méditerranéennes d'Espagne. Comptes 
Rendues XIV Congrès Géologique International, Madrid, 2, 412-521.

Gutiérrez, G., Elízaga, E., Goy, J.L., Nieto, M. \& Robles, F. 1984. Memoria Explicativa del Mapa Geológico de la Provincia de Valencia Escala 1:200.000. Diputación Provincial de Valencia, Universidad de Valencia, Instituto Geológico y Minero de España. 61 pp.

Hayek, L.A.C. \& Buzas, M.A. 1997. Surveying Natural Populations. Columbia University Press, New York, 563 pp.

Hayward, B.W., Le Coze, F. \& Gross, O. 2017. World Foraminifera Database. http://www.marinespecies.org/ foramifera.

Hemleben, C., Spindler, M. \& Anderson, O.R. 1989. Modern Planktonic Foraminifera. Springer-Verlag, New York, $363 \mathrm{pp}$.

Hilgen, F.J., Krijgsman, W., Raffi, I., Turco, E. \& Zachariasse, W.J. 2000. Integrated stratigraphy and astronomical calibration of the Serravallian/Tortonian boundary section at Monte Gibliscemi (Sicily, Italy). Marine Micropaleontology, 38, 181-211; doi: 10.1016/S03778398(00)00008-6.

Hilgen, F.J., Abdul Aziz, H., Krijgsman, W., Raffi, I. \& Turco, E. 2003. Integrated stratigraphy and astronomical tuning of the Serravallian and lower Tortonian at Monte dei Corvi (Middle-Upper Miocene, northern Italy). Palaeogeography, Palaeoclimatology, Palaeoecology, 199, 229-264; doi: 10.1016/S0031-0182(03)00505-4.

Hill, M.O. 1973. Diversity and evenness: a unifying notation and its consequences. Ecology, 54, 427-431.

Huddleston, P.F. 1984. Planktonic foraminiferal biostratigraphy, Deep Sea Drilling Project Leg 81. In: Initial Reports of the Deep Sea Drilling Project (eds. Roberts, D.G., Schnitker, D. et al.), 81, 429-438.

Iaccarino, S. 1985. Mediterranean Miocene and Pliocene planktic foraminifera. In: Plankton Stratigraphy (eds. Bolli, H.M., Saunders, J.B. \& Perch-Nielsen, K.). Cambridge University Press, 283-314.

Iaccarino, S., Lirer, F., Bonomo, S., Caruso, A., Di Stefano, A., Di Stefano, E., Foresi, L.M., Mazzei, R., Salvatorini, G., Sprovieri, M., Sprovieri, R. \& Turco, E. 2004. Astrochronology of Late Middle Mediterranean sections. In: Cyclostratigraphy: an Essay of Approaches and Case Histories (eds. D’Argenio, B., Fischer, A.G., Premoli Silva, I., Weissert, H. \& Ferreri, V.). University of Colorado. SEPM, Special Publication, 81, 25-42.

IGME, 1975. Memoria del Mapa Geológico de España Escala 1:50.000. Onteniente. $49 \mathrm{p}$

IGME, 1976. Memoria del Mapa Geológico de España Escala 1:50.000. Canals. $37 \mathrm{pp}$.

Jost, L. 2006. Entropy and diversity. Oikos, 113, 363-375.

Kaiho, K. 1994. Benthic foraminiferal dissolved-oxygen index and dissolved-oxygen levels in the modern ocean. Geology, 22, 719-722; doi: 10.1130/0091-7613(1994)022<0719:BF DOIA $>2.3 . \mathrm{CO} ; 2$.

Kaiho, K. 1999. Effect of organic carbon flux and dissolved oxygen on the benthic foraminiferal oxygen index (BFOI). Marine Micropaleontology, 37, 67-76; doi: 10.1016/ S0377-8398(99)00008-0.
Kennett, J.P. \& Srinivasan, M.S. 1983. Neogene Planktonic Foraminifera. A Phylogenetic Atlas. Hutchinson Ross Publishing Company, 265 pp.

Laskar, J., Joutel, F. \& Boudin, F. 1993. Orbital, precessional and insolation quantities for the Earth from $-20 \mathrm{Myr}$ to +10 Myr. Astronomy and Astrophysics, 270, 522-533.

Lirer, F. \& Iaccarino, S.M. 2005. Integrated stratigraphy (cyclostratigraphy and biochronology) of late Middle Miocene deposits in the Mediterranean area and comparison with the North and Equatorial Atlantic Oceans: síntesis of the major results. Terra Nova, 17, 338-349; doi: 10.1111/j.1365-3121.2005.00619.x.

Lirer, F. \& Iaccarino, S.M. 2011. Mediterranean Neogene historical stratotype sections and Global Stratotype Section and Points (GSSP): state of the art. Annalen des Naturhistorischen Museums in Wien, Serie A, 113, 67-144.

Lirer, F., Caruso, A., Foresi, L.M., Sprovieri, M., Bonomo, S., Di Stefano, A., Di Stefano, E., Iaccarino, S.M., Salvatorini, G., Sprovieri, R. \& Mazzola, S. 2002. Astrochronological calibration of the upper Serravallian/lower Tortonian sedimentary sequence at Tremiti Islands (Adriatic Sea, southern Italy). Rivista Italiana di Paleontologia e Stratigrafia, 108, 241-256; doi: 13130/2039-4942/5473.

Lirer, F., Caruso, A., Foresi, L.M., Iaccarino, S. \& Iacumin, P. 2004. Paleoclimatic changes in the Serravallian record of the Mediterranean area. In: Proceedings of the First Italian Meeting on Environmental Micropaleontology (eds. Coccioni, R., Galeotti, S. \& Lirer, F.), Grzybowsky Foundation Special Publication, 9, 77-96.

Lirer, F., Cascella, A., Cesarano, M., Casciello, E. \& Pappone, G. 2007. Micropaleontological study of the Miocene calcareous turbidite deposits of Faeto and Tufillo formations (eastern sector of the southern Appennine chain). Rivista Italiana di Paleontologia e Stratigrafia, 113, 269-286; doi: 10.13130/2039-4942/5874.

López García, M.J. \& Bustillo, M.A. 1994. Los sedimentos con diatomeas del Mioceno de la Cuenca del Guadalquivir: Edad y composición litológica. Estudios Geológicos, 50, 71-90.

Lourens, L.J., Hilgen, F.J., Shackleton, N.J., Laskar, J. \& Wilson, D. 2004. The Neogene Period. In: Geological Time Scale 2004 (eds. Gradstein, F.M., Ogg, J.G. \& Smith, A.G.). Cambridge University Press, 409-440.

Martinotti, G.M. 1981. Biostratigraphy and planktonic foraminifera of the Late Eocene to ?Pleistocene sequence in the Ashqelon 2 well (Southern Coastal Plain, Israel). Revista Española de Micropaleontología, 13, 343-381.

Martins, M.V. \& Dragão Gomes, V. 2004. Foraminiferos da Margem Continental NW Ibérica. Sistemática, Ecologia e Distribuição (ed. Figueiredo Gomes, C.), 377 pp.

Mazza, P. 1985. On the occurrence of Neogloboquadrina acostaensis in the upper Serravallian sediments of Sicily. Rivista Italiana di Paleontologia e Stratigrafia, 91, 513518.

Miller, K.G., Aubry, M.P., Khan, M.J., Melillo, A.J., Kent, D.V. \& Berggren, W.A. 1985. Oligocene-Miocene biostratigraphy, magnetostratigraphy and isotopic stratigraphy of western North Atlantic. Geology, 13, 257- 
261; doi: 10.1130/0091-7613(1985)13\%3c257:OBMAIS $\% 3 \mathrm{E} 2.0 . \mathrm{CO} ; 2$

Miller, K.G., Feigenson, M.D., Wright, J.D. \& Clement, B.M. 1991. Miocene isotope reference section, DSDP Site 608: An evaluation of isotope and biostratigraphic resolution. Paleoceanography, 6, 33-52; doi: 10.1029/90PA01941.

Murray, J.W. 2006. Ecology and Applications of Benthic Foraminifera. Cambridge University Press. Cambridge.

Papp, A. \& Schmid, M.E. 1985. Die Fossilen Foraminiferen des Tertiären Beckens von Wien. Abhandlungen der Geologischen Bundesanstalt, Wien, 311 pp.

Pearson, P.N., Wade, B.S. \& Huber, B.T. 2018. Taxonomy, biostratigraphy and phylogeny of Oligocene Globigerinitidae (Dipsidripella, Globigerinita, and Tenuitella). In: Atlas of Oligocene Planktonic Foraminifera (eds. Wade, B.S., Olson, R.K., Pearson, P.N., Huber, H.T. \& Berggren, W.A.). Cushman Foundation for Foraminiferal Research, Special Publication, 46, 429-459.

Pujol, C. \& Vergnaud Grazzini, C. 1995. Distribution patterns of live planktic foraminifers as related to regional hydrography and productive systems of the Mediterranean Sea. Marine Micropaleontology, 25, 187-217; doi: 10.1016/0377-8398(95)00002-I.

Russo, B., Sgarrella, F. \& Gaboardi, S. 2002. Benthic foraminifera as indicators of paleoecological bottom conditions in the Serravallian Tremiti sections (Eastern Mediterranean, Italy). Rivista Italiana di Paleontologia e Stratigrafia, 108, 275-287; doi: 10.13130/2039-4942/5475.

Saavedra, J.L. 1961. Los foraminíferos del Terciario superior y Cuaternario del valle del Guadalquivir. Boletín del Instituto Geológico y Minero de España, 72, 349-468.

Spezzaferri, S. 1992. Il Limite Oligo/Miocene nel 'record oceanico' (Atlántico, Indiano, Pacifico): Biostratigrafia e Paleoclimatologia. Ph.D. Thesis, Milan University (unpublished).

Sprovieri, M., Caruso, A., Foresi, L.M., Bellanca, A., Neri, R., Mazzola, S. \& Sprovieri, R. 2002a. Astronomical calibration of the upper Langhian / lower Serravallian record of Ras Il-Pellegrin section (Malta Island, Central Mediterranean). Rivista Italiana di Paleontologia e Stratigrafia, 108, 183-193; doi: 13130/2039-4942/5469.

Sprovieri, R., Bonomo, S., Caruso, A., Di Stefano, A., Di Stefano, E., Foresi, L.M., Iaccarino, S.M., Lirer, F., Mazzei, R. \& Salvatorini, G. 2002b. An integrated calcareous plankton biostratigraphic scheme and biochronology for the Mediterranean Middle Miocene. Rivista Italiana di Paleontologia e Stratigrafia, 108, 337-353; doi: 13130/2039-4942/5480.

Thunell, R. \& Sautter, L.R. 1992. Planktonic foraminiferal faunal and stable isotopic indices of upwelling: a sediment trap study in the San Pedro Basin, Southern California Bight. In: Upwelling Systems: Evolution since the Early Miocene (eds. Summerhayes, C.P., Prell, W.L. \& Emeis, K.C.). Geological Society Special Publication, 64, 77-91.

Turco, E., Hilgen, F.J., Lourens, L.J., Shackleton, N.J. \& Zachariasse, W.J. 2001. Punctuated evolution of global climate cooling during the late Middle to early Late Miocene: High-resolution planktonic foraminiferal and oxygen isotope records from the Mediterranean. Paleoceanography, 16, 405-423; doi: 10.1029/2000PA000509.

Turco, E., Bambini, A.M., Foresi, L., Iaccarino, S., Lirer, F., Mazzei, R. \& Salvatorini, G. 2002. Middle Miocene highresolution calcareous plankton biostratigraphy at Site 926 (Leg 154, equatorial Atlantic Ocean): palaeoecological and palaeobiogeographical implications. Geobios, mem. spec., 24, 257-276; doi: 10.1016/S0016-6995(02)00064-5.

Usera, J. 1972. Paleogeografía del Mioceno en la provincia de Valencia. Boletín de la Real Sociedad Española de Historia Natural. Sección Geológica, 70, 307-315.

Usera, J. 1973. Nuevas especies de foraminíferos de la provincia de Valencia. Parte I. Rotalia beccarii globula, COLOM, 1936, Ammonia globula (COLOM, 1936). Boletín de la Real Sociedad Española de Historia Natural. Sección Geológica, 71, 183-193.

Usera, J. 1974a. Microbioestratigrafía del Neógeno marino en la provincia de Valencia. Boletín de la Real Sociedad Española de Historia Natural. Sección Geológica, 72, 213-228.

Usera, J. 1974b. Estudio micropaleontológico (Foraminíferos) del Mioceno marino de la Sierra del Besori (Valencia). Boletín de la Real Sociedad Española de Historia Natural. Sección Geológica, 72, 203-212.

Usera, J. 1975. Las faunas de microforaminíferos miocenos de los alrededores de Valencia. Real Sociedad Española de Historia Natural. Volumen extraordinario primer Centenario (1971) 1, 465-475.

Van der Zwaan, G.J., Jorissen, F.J. \& De Stigter, H.C. 1990. The depth dependency of planktonic/benthonic foraminiferal ratios: constraints and applications. Marine Geology, 95, 1-16; doi: 10.1016/0025-3227(90)90016-D.

Van Hinsbergen, D.J.J., Kouwenhoven, T.J. \& Van der Zwaan, G.J. 2005. Paleobathymetry in the backstripping procedure: Correction for oxygenation estimates on depth estimates. Palaeogeography, Palaeoclimatology, Palaeoecology, 221, 245-265; doi: 10.1016/j.palaeo.2005.02.013.

Wade, B.S., Pearson, P.N., Berggren, W.A. \& Pälike, H. 2011. Review and revision of Cenozoic tropical planktonic foraminiferal biostratigraphy and calibration to the geomagnetic polarity and astronomical time scale. Earth-Science Reviews, 104, 111-142; doi: 10.1016/j. earscirev.2010.09.003

Zachariasse, W.J. \& Spaak, P. 1983. Middle Miocene to Pliocene paleoenvironmental reconstruction of the Mediterranean and adjacent Atlantic Ocean: planktonic foraminiferal record of Southern Italy. Utrecht Micropaleontological Bulletins, 30, 91-110.

Zachariasse, W.J. \& Sudijono 2012. New data on the morphology and classification of the Oligocene-Miocene planktonic foraminifer Paragloborotalia siakensis (LeRoy, 1939). Journal of Foraminiferal Research, 42, 156-168; doi: $10.2113 /$ gsjfr.42.2.156.

Zachos, J., Pagani, M., Sloan, L., Thomas, E. \& Billups, K. 2001. Trends, Rhythms, and Aberrations in Global Climate $65 \mathrm{Ma}$ to Present. Science, 292, 686-693; doi: 10.1126/ science. 1059412. 
